\title{
Economic-Financial Profile of Companies Which Do And Don't Do Assets Reevaluation
}

\author{
Eliandro Schvirck ${ }^{\dagger}$ \\ Technology University of Paraná \\ Oldair Roberto Giasson ${ }^{\ddagger}$ \\ Technology University of Paraná
}

\begin{abstract}
The evaluation of assets through the historical cost presents limitations in its informative power due to the value imbalance, thus the accounting values can be unreal front to the market. An alternative to decrease the impact of the value imbalance on the permanent assets, which are most sensible to this fact, is the evaluation to the current cost. The Brazilian legislation allows to the companies the alternative of assets reevaluation through the value of market, thus, some companies use this procedure and others not. In this context, the present study had as objective to investigate the economic-financial profile of these two groups of companies to verify if significant differences between them exist. We used for this the group of companies which displays its statements in São Paulo Stock Exchange (BOVESPA), totalizing 261 companies. With the intention of evaluating the significance of the existing differences, the non-parametric test of hypotheses Mann Whitney was used. The results point to the existence of significant differences in the profile of the two groups of companies.
\end{abstract}

Keywords: assets measurement; assets reevaluation, economics indexes; accounting statements.

\footnotetext{
Received in 05/16/2008; revised in 10/19/2008; accept in 04/12/2008.

Corresponding authors:

${ }^{\dagger}$ Assistant Professor of Accounting Course in Federak Technology University of Paraná - Pato Branco Campus Address: Rua Verissimo Rizzi, no.967, Bairro Fraron,

Pato Branco-PR-Brazil-CEP: 85503-370.

e-mail:eliandro@utfpr.edu.br

Telephone: (46) 9115.1434

${ }^{*}$ Assistant Professor of Accounting Course in Federak Technology University of Paraná - Pato Branco Campus Address: RuaTocantins, no. 234, Bairro Cristo Rei, Pato Branco - PR - Brazil-CEP: 85506-330. e-mail: giasson@utfpr.edu.br Telephone: (46) 9115.1252
}

Editor's note: This paper was accepted by Alexsandro Broedel Lopes. 


\section{INTRODUCTION}

The registration of property items by their entry values, that is, at acquisition cost, is the most practice most present in Accounting, especially in the reports directed at external users. Martins (2001), p.25) argues that this form or registration is the most used, due to its "[...] greater ease of identification (practicability)" and the "[...] greater ease of proof, especially due to the strong correlation with cash flow and documents of proof (objectivity)."

According to the fundamental principles of Accounting, the assets must be registered in their original value, that is, at their historical acquisition cost. This historical value, however, suffers imbalance over the years, making the company assets have unreal values in relation to the market. Until 1995, the monetary correction of fixed assets and net equity adjusted its values based on national economy indexes, providing a monetary updating of the values, aiming to maintain the acquisitive power of the company's capital. Act 249/95 extinguished monetary correction and since then assets and company capital have their values kept at the historical cost of entry into property.

Act 6.404/76 allows companies to assess their assets at market value, calling this procedure reevaluation; this, however, should not be confused with monetary correction, as in reevaluation the company uses the market value of its assets to value them, while monetary correction represents the updating of values based on an economic index.

Reevaluation consists in adjusting the value of the fixed asset in the face of the reserve reevaluation account that makes up net equity. This positive adjustment provokes an increase in the fixed asset and, consequently, in the net equity.

As it is an alternative procedure, some companies do it and others not, according to their interests. In this context, the study by Schvirck (2006, pg.127) about reevaluation practices in Brazil, shows signs of speculative reevaluation use, in situations where the company benefits with the procedure, however not fully meeting the legislative precepts in relation to the manner that the reevaluation should be carried out.

This fact may damage the comparability between companies' statements, as some property will be affected by the reevaluation values and some will not.

In this context, this study sought to verify, based on the more traditional economicfinancial indexes for demonstration analysis, if there are significant differences between the indexes of companies that do reevaluation and the indexes of those who do not, thus presenting an economic-financial profile of the two groups of companies.

This article is organized in five parts, including this introduction; below are presented the methodological procedures used for the research, the selection of companies and the statistical method used for the test; then, the theoretical referential is presented, covering forms of assets measurement, an explanation of assets reevaluation and the economicfinancial indexes used in the work; in topic four, the results and analysis of the statistical test applied to the collected data are presented; and finally, the final considerations on the study.

\section{METHODOLOGICAL PROCEDURES}

Where, according to Gil (2001, pg. 44-45), bibliographical research is developed based on material already elaborated, made up mainly of books and scientific articles; and documental research is defined as that which uses materials that have not yet been given an analytical treatment or than can still be re-elaborated according to the objects of the research in question. 
In this way, the theoretical referential for the research was developed based on bibliographical materials on the subject and the empirical part of the work was based on analysis of accounting statements from the companies listed in the BOVESPA database in the period from 2000 to 2004 .

Out of this group, companies were excluded which had presented less than four years of statements in the stipulated period. Companies from the banking and insurance sector were also discarded, as they have specific legislation and accounting standards that are distinct from other sectors.

The sample was made up of 261 companies from various sectors. This group was separated into two: companies with reevaluation and companies without reevaluation.

Once the sample had been defined, the annual performance indictors for the companies were calculated, that is, current liquidity, general liquidity, total debt, participation of third party capitals, debt composition, immobilization of net equity, immobilization of non-current resources, net margin, return on net equity and return on assets.

Considering the purpose of this study, the set of indexes listed adequately characterizes the financial and property structure of companies, thus allowing the analysis proposed here.

Thus, this study's database was made up of 1291 observations, formed by the annual indexes of all the companies and with, in some cases, the company presenting only four years of statements and not five, as has already been explained.

The statistical treatment of the data took place by using the statistical package SPSS 13.0, through applying the Mann Whitney non-parametric hypothesis test indicated by Stevenson (2001, p.317) and Martins (2002, p.268) to be used when testing whether two independent samples come from populations with equal averages.

Based on this definition, this technique applies well to this study, as the latter proposed to evaluate if there are significant differences in the performance indexes of the selected two groups of companies.

The hypotheses to be tested are:

- $\mathrm{H}_{0}=$ the averages are the same, therefore there aren't significant differences in the indexes of the two groups of companies;

- $\mathrm{H}_{1}=$ the averages are different, therefore there are significant differences in the indexes of the two groups of companies.

The Mann Whitney test is based on a sum of posts, or classifications. Firstly, it is necessary to order all the data as if they were a single sample, in ascending order. After they have been ordered, the lowest score is given to the first post, continuing with the classification until: $\mathrm{n}=\mathrm{n}_{1}+\mathrm{n}_{2}$.

According to Stevenson (2001, p.317) when $\mathrm{H}_{0}$ is true, the posts must be distributed in an even manner between the two samples. For $\mathrm{H}_{1}$ to be true a sample will tend to have lower posts, and consequently a lower sum of posts, while the other will tend to have a higher sum of posts.

The Komolgorov-Smirnov test verifies the normality of the population, that is, if the indexes presented in the sample have a normal distribution or not.

The alpha level established for the tests in this study was 0.05 , thus the results obtained can be considered correct at the $95 \%$ confidence level. As the results can be both greater and lower, that is, it is a two-tailed test, the alpha level to be considered in the tests is 0.025 , that is, 0.05 divided by two, completing the percentage in each tail of the probability curve.

The value $\mathrm{Z}$, shown in the tests, represents the magnitude of the difference in the group averages and must be analyzed in comparison to the $t$ student value. The $t$ value for this test, 
considering the number of observations, 1291, and the alpha level, 0.025, is 1.9600, as presented by Martins (2002, pg. 366).

Thus, the higher the value of $\mathrm{Z}$ is, the more distant are the averages of the companies contained in the sample.

\section{ASSETS MEASUREMENT}

Accounting theory presents two assets measurement forms, entry values and exit values. According to Hendriksen and Van Breda (1999, pg. 303), entry values are represented by the assets acquisition costs and exit measures represent the assets sale value in the market, both can be extracted from past, current or future markets.

Ludicibus (2004, pg. 142) comments that in "[...] all theories for assets measurement is found the wish for evaluation to represent the best possible quantification of the services potentials that the assets presents for the entity." Therefore, no form of measurement can be considered more correct than another, they simply apply to different situations.

Still in this context, Hendriksen and Van Breda (1999, p. 305) argue that generally goods and services are exchanged for money, so the exchange prices (market prices) must be relevant for divulging. Considering that economic decisions only affect current or future values, the exchange price on these value bases are as important as the past values; thus, the three measurement forms must be examined.

The accounting principle of registration by original value follows the theory of entry measurements based on past values, that is, the historic cost is the form of measurement prescribed by this principle and it is defined by Hendriksen and Van Breda (1999, pg. 306) as "[...] the aggregated price paid by the company to acquire the property and the use of an assets, including all payments necessary to place the asset at the location and the conditions that allow rendering services in production or other company activities."

The registration of assets based on historical cost presents two disadvantages in relation to the informative power of this value, for with the passing of time the value of the asset can vary and have little, or no, significance as a monetary measure of resources available to the company.

As they remain for a long period of time in the company's property, non-current assets are more affected by price variations than current assets, which circulate more quickly in the company.

To minimize this loss of relevance in the values of the assets registered by historical value, another possible form of measurement is registration by current costs, which Hendriksen and Van Breda (1999, p. 308) define as "[...] the exchange price that would be demanded today to obtain the same asset or an equivalent asset", that is, the asset's purchase price in the market.

The same authors $(1999$, p.308) alert, however, that to use the current cost method, the exchange value must be obtained from quotations in a market where the company acquires its assets or services and not in the market in which the company usually sells its assets or services in the normal course of its operations, unless both markets coincide.

In this context, the assets undergo a process of reevaluation from the historical cost to the current cost and when the assets are reevaluated, new measurement bases are needed. 


\section{ASSETS REEVALUATION IN BRAZIL}

According to Martins (1992, pg. 110), reevaluation means, in Accounting, the attribution of new value to an asset, preferentially a fixed asset that will continue being used by the company as it pursues its goals.

Assets reevaluation was instituted in Brazil by act 6.404/76, article 182, paragraph 3, allowing assets evaluated at historical acquisition cost to be evaluated at their market price.

Act 6.404/76 mentions that the reevaluation will be of the asset's elements, however deliberation 183/95, of the CVM (Securities and Exchange Commission of Brazil), limits the reevaluation to the tangible property of the fixed asset and as long as it is not designed to be discontinued.

Fiscal legislation, through article 3.000, article 434, accepts reevaluation for assets, except investments evaluated by equity equivalence. In this case, the reevaluation applied to current and long-term assets in considered taxable revenue.

In the case of the reevaluation of the permanent asset the taxation differs according to the realization of the reevaluated property, by depreciation or reduction. This study will not go into an in-depth discussion of the tax aspect of reevaluation, for the subject merits a specific work with possibilities for more details.

According to Ludicibus, Martins and Gelbcke (2003, pg. 314), the reevaluation of the fixed asset tends to be of great importance within the property, especially due to theimbalance that takes place in the historical value of the property over time, for this updates the property to the market value, bringing it closer to its real value.

Accounting has not aimed at registering property at market value, for this is in property for use and generation of wealth and not for commercialization. For this reason, it is registered at its original value (historical cost) so that it can be lowered, in the form of depreciation, in order for the consumed value of this property in each period to be adequately appropriated. However, as expressed by Ludicibus, Martins and Gelbcke (2003, pg. 314), if Accounting becomes tied to this way of proceeding, it can move away from a purpose that increasingly comes under its responsibility: the evaluation of property and the re-composition of its physical long-duration part.

The same authors (2003, pg. 315) differentiate depreciation by historical cost and by reevaluated values, expressing that:

\section{[...] depreciation by historical value does not mean retaining resources to replace the asset, but rather to recover the invested capital, [...] with the reevaluation, adjusting the value of the property to the market value, there is the retention of an additional part of cash over the depreciation period needed for the replacement of the asset.}

It is understood that in this way Accounting is concerned with the responsibility given to it, as mentioned above.

When a company opts for reevaluation it abandons historical cost as an asset evaluation criteria and starts using the current value or market value of the property.

According to CVM decision 183/95 and CFC (Federal Accounting Council) resolution $1004 / 04$, the reevaluations can be periodical, in order to avoid significant differences in relation to the market value of the assets on the date of each balance. The following periods should be observed: 
a. annually, for the account or group of accounts that have market values which vary significantly in relation to values previously registered;

b. every four years, for assets that do not have a relevant market price oscillation, including property acquired after the last reevaluation;

c. once the concept and the periods presented have been observed, the company may opt for a rotation system, periodically doing partial reevaluations, on a rota basis, with defined time schedules, covering all the assets and reevaluate everyperiod.

Still in accordance with CFC resolution 1004/04, this procedure must be maintained for at least 10 (tem) years, after this period, if the company chooses not to reevaluate, the property will remain with its reevaluated values.

The procedure for reevaluation according to Martins (1992, p.303), must “[...] consider the value of replacement of the property in the state in which it is found and the possibility of performing the addition of the asset reevaluation through the company's future operations."

The value of the reevaluation is the difference between the market value found by the technical report and the accounting value (cost minus accumulated depreciation) registered in the company's property.

According to Martins (1992, p. 110), “[...] reevaluation will exist only when the value found is superior to the accounting value", if the reevaluation process presents a negative value this will be compensated with the existing values and if there are no prior reevaluations the negative value will not be registered.

The reevaluation will be reflected in the property with the increase of the reevaluated asset in the face of the net equity in the reevaluation reserves account, the performance of this reserve will took place by reducing the reevaluated property, by depreciation or alienation, in the face of the accumulated profits account. Martins (1992, p. 302) argues that "[...] the incorporation to accumulated profits corresponds to the effective performance of the potential revenue registered on occasion of the constitution of the reevaluation reserve." Ludicibus, Martins and Gelbcke (2003, pg. 321-322) present some consequences of assets reevaluation, including:

- updating of results - by the registration of the depreciation of property reevaluated as expenses (or product costs), considering that this value is closer to reality in terms of replacement price of the assets that the company will need to replace in the future;

- better evaluation of the asset, the net equity and the property value of the action reevaluation provides an approximation of the property's value to its real market value, thus, there is an assets on more current bases and a net equity value that is also more up to date;

- better presentation of the profitability indexes - a more up to date value of the profits and also a more current measure of net equity allow more adequate calculation of the proprietors' investment returns; the tendency is for this index to reduce nominally, but what is actually happening is, with the verification of the more real index, the one calculated based on old values may be deceptive;

- better presentation of the financial solidity indexes - with the value of the asset and the net equity more updated there is, for example, a more realistic comparison with the value of the liabilities. The indexes of liability / net equity are more expressive and, in this case, they become more favorable to the company, better representing its true situation.

According to Ludicibus, Martins and Gelbcke (2003, pg. 315).

[...] many companies have been using reevaluations to deliberately

BBR, Braz. Bus. Rev. (Eng. ed., Online),

Vitória, v. 5, n. 3, Art. 6, p. 242 - 257, sep.- dec. 2008

www.bbronline.com.br 
replaced. Other companies do the reevaluation when they feel that their net equity is low and the debt equity indexes are compromising.

In line with the authors' arguments, this research analyzes, through economic-financial indexes, if the companies that do reevaluation present significantly different indexes from companies that do not. Before, however, some indexes that are the basis for this study are commented.

\section{PERFORMANCE INDEXES}

One of the techniques used by accounting professionals to analyze the economicfinancial condition of companies is the use of performance indexes, also knows as balance analysis indexes.

These indexes are defined by various authors in the specialized literature, including by Silva (2003, pg. 216), who says that "[...] financial indexes are relationships between accounts or groups of accounts of financial statements, the purpose of which is to provide information that is not easily visualized directly in financial statements."

Similarly, Matarazzo (2003, pg. 147) describes indexes as "[...] the relationship between accounts or group of accounts of financial statements, which aim to show a certain aspect of a company's economic or financial situation."

Matarazzo (2003, pg. 147) argues that "[...] the fundamental characteristic of the indexes is to provide a broad view of a company's economic or financial situation."

Based on these definitions and highlighting that the purpose of this study is not to give a detailed analysis of the economic-financial condition of the selected companies, the economic-financial indexes were used as a tool for comparing the companies contained in the sample, since, according to Silva (2003, pg. 216) "[...] as a relative measure of quantity the index allows comparison, at a certain moment or period, of a company's index with the same one relative to other companies," this comparison is not practicable if absolute values are considered.

However, it is important to highlight that the analysis by indexes has limitations to its indiscriminate use, as has already been expressed. The indexes present a broad view of companies' situation and, besides, Shrickel (1999, p.124) warns that "[...] it is fundamental to keep in mind that the figures of the statements can be affected by macro and microeconomic oscillations, taking place during the accounting period, which are beyond the company's control," and also that the values of the accounting statements "[...] may have been artificially affected by alterations in the accounting procedures, without this having been motivated by any fraudulent motive."

Considering these observations, it is important to highlight that the results found in this study are limited to these points, since the balances used were not analyzed deeply so as to adjust them to any occurrences that affected them.

According to Matarazzo (2003, p. 148), it's not important to calculate a large number of indexes to arrive at a good analysis result, it is necessary to present a set of indexes that allow the company's situation to be known.

The same author (2003, pg. 149) argues that "[...] the analysis of industrial and commercial companies through traditional indexes should have at least four and there is no need to extend beyond eleven indexes." 
For this study, a set of indexes was selected to cover the three fundamental analysis points highlighted by Matarazzo (2003, pg. 150) and Marion (2001, pg. 13): structure, liquidity and profitability.

The structural dimension presents the company's policies with respect to obtaining and applying resources, if the company will work with third party capital or its own, how much of the capital obtained will be applied in fixed assets, among other decisions.

- immobilization of net equity: permanent asset divided by net equity - represents the company's investment policy on its fixed assets, indicates what proportion of net equity was invested in fixed assets and how much is circulating in the company's activity, which is known as own working capital;

- immobilization of non-current resources: permanent asset divided by long-term liabilities plus net equity - similar to the immobilization of net equity index, indicates what proportion of own and long-term capital is invested in the company's fixed assets. This index is important when the immobilization of net equity index is higher than 1 , or $100 \%$, because having immobilized more than $100 \%$ of its net equity, the index of non-current resource immobilization will indicate if the company is immobilizing current resources;

- the index of total debt: total liabilities divided by liabilities plus net equity - demonstrates the composition of third party capital and own capital in the total resources available to the company, that is, what is the existing proportion of third party capital, compared to the total liabilities plus net equity;

- the index of third party capital participation: total liabilities divided by net equity presents what is the proportion of third party capital in the company, compared to the total own capital or net equity;

- debt composition: current liabilities divided by total liabilities - represents the proportion of debt which has short-term maturity, also influencing the company's financial condition.

In the financial aspect we see company liquidity, according to Matarazzo (2003, pg. 163), the liquidity indexes seek to measure the solidity of the company's financial bases.

These indexes are relationships between current assets and liabilities accounts or for long-term realizable/liability. Theoretically, these indexes represent the company's capacity to pay its debts; theoretically, because in its analysis, among other factors, the temporal aspect must be considered. The maturity of assets will rarely coincide with that of the liabilities, therefore the real payment capacity will only be known through the daily management of entry and exit cash flow.

- Current liquidity: current assets divided by current liabilities - represents the capacity which, theoretically, the company has to settle its short-termobligations.

- General liquidity: current assets plus long-term realizable divided by current liabilities plus long-term liabilities - represents the capacity that the company has to, theoretically, honoring its short and long-term commitments.

The economic aspect is basically made up of the profitability indexes and they represent, according to Matarazzo (2003, pg. 175), “[...] how much the investments have yielded and what the company's economic degree of success is." The profitability indexes used in the research together represent the yield from the company's three main aspects, the operational, the investor and the investment.

- Net margin: net profit divided by the net sales income - this index finds how much the company can generate in profits with its sales operations, it shows the profitability of the company's activity.

- Return on net equity: net profit divided by initial net equity - it is the return that the investor has with the company, how much the profit generated by the activity represents 
over the investment performed by the shareholder, to Ludicibus, Martins and Gelbcke (2003, pg. 322), "[...] the best way of measuring the company's profitability is with the calculation of the return (net profit) over net equity."

- Return on assets: net profit divided by the total average assets - it is the index that presents the company's capacity for generating results with the investments performed in its assets. According to Matarazzo (2003, pg. 179), "[...] it is not exactly a profitability index, but rather, a measure of the company's potential for profit generation."

\section{PRESENTATION AND ANALYSIS OF RESULTS}

The statistical analysis is performed through the Mann-Whitney non-parametric hypotheses test. This test, according to Stevenson (2001, pg. 317) and Martins (2002, pg. 268 ), is used to test if two independent samples were taken from populations of equal averages. In this way, this test meets the purposes proposed in this study, that is, to test if there are significant differences between the averages of the companies that use reevaluation and those that don't.

Martins (2002, pg. 269) presents the hypotheses to be tested by this statistical tool as being:

- $\mathrm{H}_{0}=$ there is no difference between the groups, that is, the averages are the same;

- $\mathrm{H}_{1}=$ there is a difference between the groups, that is, the averages are not the same.

Below, the results of the tests applied will be commented, the indexes will be analyzed by groups as stated before, or:

- financial: current liquidity and general liquidity;

- structure: immobilization of net equity, immobilization of non-current resources, total debt, participation of third party capital and composition of debt;

- economical: net margin, return on net equity and return on assets.

\subsection{Financial indexes}

Considering the results presented in the following tables it can be said that in the group of financial indexes the null hypothesis $\left(\mathrm{H}_{0}\right)$ cannot be accepted, that is, there are significant differences in the indexes between the companies that use reevaluation and those that do not. These conclusions stem from the analysis of the index Asymp. Sig. (2-tailed) in Table 1, the sig of 0.000 is lower than the alpha level determined for the test, showing that the averages are not the same.

The $\mathrm{Z}$ Test for these indexes, shown in Table 1, presents values much higher than the acceptable value of $t$. This means that the difference between the averages is quite significant. The biggest difference is between the averages in general liquidity, which presented a $\mathrm{Z}$ value of 6.855 , while current liquidity was 5.665 , remembering that the $t$ value for this test is 1.96 . 
Table 1 - Test Statistics(a)

\begin{tabular}{l|l|l}
\hline & Current liquidity & General liquidity \\
\hline Mann-Whitney $U$ & 167869.000 & 159951.000 \\
Wilcoxon $W$ & 331175.000 & 323257.000 \\
$Z$ & -5.665 & -6.855 \\
Asymp. Sig. (2-tailed) & .000 & .000 \\
\hline a Grouping Variable: Classification
\end{tabular}

In Table 2 it can be seen that the average of the scores is greater for the group of companies without reevaluation than for those with reevaluation, that is, the group of companies without reevaluation has higher posts, while the companies with reevaluation have more low posts. According to the comment by Stevenson (2001, pg. 317), for the equality of averages hypothesis to be accepted, the sum of the scores must be balanced. This way, it can be inferred that the financial indexes of the companies that do reevaluation are smaller, that is, the companies that do not do reevaluation present better indexes for the capacity to pay their obligations.

Table 2 - Ranks

\begin{tabular}{l|l|l|l|l}
\hline & Classification & N & $\begin{array}{l}\text { Mean } \\
\text { Rank }\end{array}$ & $\begin{array}{l}\text { Sum of } \\
\text { Ranks }\end{array}$ \\
\hline Current liquidity & Without reevaluation & 720 & 698.35 & 502811.00 \\
& With reevaluation & 571 & 579.99 & 331175.00 \\
& Total & 1291 & & \\
General liquidity & Without reevaluation & 720 & 709.35 & 510729.00 \\
& With reevaluation & 571 & 566.12 & 323257.00 \\
& Total & 1291 & & \\
\hline
\end{tabular}

In Table 3 the Komolgorov-Sminorv normality test also presents the sig in 0.000 , lower than the 0.025 alpha determined for this study. Thus, it can be concluded that there is no normalityin the sample data. The $\mathrm{Z}$ value presents the same characteristics of Table 1.

Thus, we can conclude that statistically, the averages of the financial indexes of the selected companies, considering the segregation of the groups, cannot be considered equal.

Table 3 - Test Statistics(a)

\begin{tabular}{|c|c|c|}
\hline & Current liquidity & General liquidity \\
\hline $\begin{array}{l}\text { Most Extreme Absolute } \\
\text { Differences }\end{array}$ & .167 & .199 \\
\hline Positive & .004 & .002 \\
\hline Negative & -.167 & -.199 \\
\hline Kolmogorov-Smirnov $Z$ & 2.977 & 3.553 \\
\hline Asymp. Sig. (2-tailed) & .000 & .000 \\
\hline
\end{tabular}




\subsection{Structure indexes}

In these indexes the null hypothesis $\left(\mathrm{H}_{0}\right)$ cannot be accepted, that is, statistically there are significant differences in the indexes between the companies that do reevaluation and those that don't. This can be seen in the analysis of the Asymp. Sig. (2-tailed) index in Table4, where the sig of 0.000 is lower than the alpha level determined for the test, showing that the averages are not equal.

An exception is the sig of the debt composition index, which is 0.028 , being therefore within the acceptance area of the alpha level, that is, the hypothesis of averages equality can be accepted. The $\mathrm{Z}$ value is 2.191 , which in this case is in the area of rejection of test $t$, with it not being possible to accept the hypothesis of equality. It can be seen that the two tests are very close to the acceptable limits and perhaps for this reason present a certain divergence.

Test $\mathrm{Z}$, in Table 4, presents values above the acceptable value of $\mathrm{t}$, this means that the differences between the averages are significant. The difference between NE immobilization averages was the greatest, presenting $\mathrm{Z}$ at 6.906 , while the smallest difference occurred in the debt composition index, where the $\mathrm{Z}$ was 2.191 .

Table 4 - Test Statistics(a)

\begin{tabular}{|c|c|c|c|c|c|}
\hline & $\begin{array}{l}\text { NE } \\
\text { immobilizatio } \\
n\end{array}$ & $\begin{array}{l}\text { Immobilization } \\
\text { of non-current } \\
\text { resources }\end{array}$ & Total debt & $\begin{array}{l}\text { Participation } \\
\text { of third party } \\
\text { capital }\end{array}$ & $\begin{array}{l}\text { Debt } \\
\text { composition }\end{array}$ \\
\hline $\begin{array}{l}\text { Mann- } \\
\text { Whitney U }\end{array}$ & 118057.000 & 132003.000 & 170915.000 & 135186.000 & 190982.000 \\
\hline $\begin{array}{l}\text { Wilcoxon } \\
W\end{array}$ & 324460.000 & 340338.000 & 430475.000 & 342876.000 & 354288.000 \\
\hline$Z$ & -6.906 & -4.443 & -5.207 & -3.923 & -2.191 \\
\hline $\begin{array}{l}\text { Asymp. Sig. } \\
\text { (2-tailed) }\end{array}$ & .000 & .000 & .000 & .000 & .028 \\
\hline
\end{tabular}

a Grouping Variable: Classification

The analysis of Table 5 shows that the average of the scores is greater for the group of companies with reevaluation than for those without reevaluation, so the group of companies with reevaluation has more high posts, while the companies without reevaluation have more low posts. Thus, it can be inferred that the structure indexes of the companies that do reevaluation are greater. It can therefore be said that the companies that do reevaluation present greater debt and capital immobilization indexes. 
Table 5 - Ranks

\begin{tabular}{l|l|l|l|l}
\hline & Classification & N & $\begin{array}{l}\text { Mean } \\
\text { Rank }\end{array}$ & $\begin{array}{l}\text { Sum } \\
\text { Ranks }\end{array}$ \\
\hline NE Immobilization & Without reevaluation & 642 & 505.39 & 324460.00 \\
& With reevaluation & 484 & 640.58 & 310041.00 \\
& Total & 1126 & & \\
Immobilization of non-current & Without reevaluation & 645 & 527.66 & 340338.00 \\
resources & With reevaluation & 484 & 614.77 & 297547.00 \\
& Total & 1129 & & \\
Total debt & Without reevaluation & 720 & 597.88 & 430475.00 \\
& With reevaluation & 571 & 706.67 & 403511.00 \\
Participation \\
capital
\end{tabular}

The Komolgorov-Sminorv normality test, in Table 6, also presents a sig at 0.000 lower than the alpha level of 0.025 determined for this study. Thus, it can be concluded that the sample doesn't come from a population with a normal distribution, except in the debt composition index.

For this index, the $\mathrm{Z}$ value found is at 1.822 , lower than the acceptable value for $\mathrm{t}$. Thus, it can be said that for this index the sample comes from a normal population.

To sum up, having analyzed the tests, it cannot be said that there is equality in the averages of the structure indexes in the group of companies selected. 
Table 6 - Test Statistics(a)

\begin{tabular}{|c|c|c|c|c|c|}
\hline & $\begin{array}{l}\text { Immobiliz } \\
\text { ed NE }\end{array}$ & $\begin{array}{l}\text { Non-current } \\
\text { immobilized } \\
\text { resources }\end{array}$ & $\begin{array}{l}\text { Total } \\
\text { debt }\end{array}$ & $\begin{array}{l}\text { Participati } \\
\text { on of third } \\
\text { party } \\
\text { capital }\end{array}$ & $\begin{array}{l}\text { Debt } \\
\text { composition }\end{array}$ \\
\hline $\begin{array}{l}\text { Most Extreme Absolute } \\
\text { Differences }\end{array}$ & .184 & .132 & .129 & .119 & .102 \\
\hline Positive & .184 & .132 & .129 & .119 & .023 \\
\hline Negative & -.006 & -.017 & -.004 & -.010 & -.102 \\
\hline $\begin{array}{l}\text { Kolmogorov-Smirnov } Z \\
\text { Asvmp. Sig. (2-tailed) }\end{array}$ & $\begin{array}{l}3.059 \\
.000\end{array}$ & $\begin{array}{l}2.202 \\
.000\end{array}$ & $\begin{array}{l}2.308 \\
.000\end{array}$ & $\begin{array}{l}1.987 \\
.001\end{array}$ & $\begin{array}{l}1.822 \\
.003\end{array}$ \\
\hline
\end{tabular}

a Grouping Variable: Classification

\subsection{Economic indexes}

The data presented in the tables indicates that in the economic indexes the null hypothesis $\left(\mathrm{H}_{0}\right)$ cannot be accepted, that is, there are significant differences in the indexes of companies who do reevaluation and those who do not. This is noticeable in Asymp. Sig. (2tailed) in Table 7, where the sig of 0.000 is lower than the alpha level determined for the test, showing that the averages are not equal.

Test $Z$, in Table 7, presents values above the acceptable value for $t$, which means that there is a significant difference between the averages. The greatest difference is between the averages in return on assets, which presented $Z$ at 5.243, while the smallest difference occurred in the return on NE index, where $Z$ was 3.470 .

Table 7 - Test Statistics(a)

\begin{tabular}{|l|l|l|l|}
\hline & Net Margin & $\begin{array}{l}\text { Return on Net } \\
\text { Equity }\end{array}$ & Return on assets \\
\hline Mann-Whitney U & 162900.000 & 135941.000 & 167491.000 \\
Wilcoxon $W$ & 326206.000 & 250422.000 & 326821.000 \\
$Z$ & -5.181 & -3.470 & -5.243 \\
Asymp. Sig. (2-tailed) & .000 & .001 & .000 \\
\hline
\end{tabular}

a Grouping Variable: Classification

An analysis of Table 8 shows that the average of the scores of the group of companies without reevaluation is greater, so the group of companies without reevaluation has more high posts, while the companies with reevaluation have more low posts.

Thus, it can be inferred that the economic indexes of the companies that do not do reevaluation are greater, and that the companies that do not do reevaluation present greater returns for the company and for investors. 
Table 8 - Ranks

\begin{tabular}{l|l|l|l|l}
\hline & Classification & N & $\begin{array}{l}\text { Mean } \\
\text { Rank }\end{array}$ & $\begin{array}{l}\text { Sum of } \\
\text { Ranks }\end{array}$ \\
\hline Net Margin & Without reevaluation & 687 & 677.88 & 465705.00 \\
& With reevaluation & 571 & 571.29 & 326206.00 \\
& Total & 1258 & & \\
Return on NE & Without reevaluation & 647 & 591.89 & 382953.00 \\
& With reevaluation & 478 & 523.90 & 250422.00 \\
& Total & 1125 & & \\
Return on Assets & Without reevaluation & 716 & 688.57 & 493019.00 \\
& With reevaluation & 564 & 579.47 & 326821.00 \\
& Total & 1280 & & \\
\hline
\end{tabular}

The Komolgorov-Sminorv normality test, in Table 9, also presents the sig at 0.000 , lower than the alpha level of 0.025 determined for this study. Thus, it can be concluded that the sample does not come from a population with normal distribution.

Table 9 - Test Statistics(a)

\begin{tabular}{l|l|l|l}
\hline & Net margin & $\begin{array}{l}\text { Return on net } \\
\text { equity }\end{array}$ & Return on assets \\
\hline $\begin{array}{c}\text { Most Extreme Absolute } \\
\text { Differences }\end{array}$ & .168 & .135 & .155 \\
\multicolumn{1}{c|}{ Positive } & .006 & .021 & .002 \\
Negative & -.168 & -.135 & -.155 \\
Kolmogorov-Smirnov Z & 2.973 & 2.236 & 2.748 \\
Asymp. Sig. (2-tailed) & .000 & .000 & .000 \\
\hline a Grouping Variable: Classification
\end{tabular}

It must be highlighted that the difference in the sum of the scores, in the three index groups, does not refer to the difference in values between the averages of companies with and without reevaluation, but rather, in the difference of score classification.

This study was elaborated on an intentional sample, therefore, the groups of companies that make up the study were not randomly selected, as was explained in the initial part of this part, but rather they were chosen for having made their information available on the internet.

Another aspect that was not considered was reevaluation's accounting effects on the indexes, that is, the differences presented in the tests cannot be attributed simply to assets reevaluation having occurred or not, for other factors in company dynamics could influence these differences.

\section{FINAL CONSIDERATIONS}

Assets registration at their historical cost presents advantages and disadvantages. The main disadvantage relates to the informative power of historical cost, due to the imbalance in the value of the property over time. This fact is felt more strongly in non-current assets that 
stay for long periods in the company, not having the movement that current assets have, the latter being less affected by imbalance.

With the aim of reducing the effect of imbalance, law 6.404/76 instituted the possibility of reevaluating assets and the CVM, for its part, restricted this procedure to permanent assets only.

Reevaluation consists in evaluating the assets at their market value. It is important to highlight that in this new evaluation must be considered the conditions of the property to be reevaluated and the current cost must be obtained in the market where the company would buy the property and not its sale price.

As assets reevaluation is an alternative procedure, comparability between companies is damaged, for some companies have values in their permanent assets and net equity that are the fruit of a market valorization and not of investments.

When referring to assets proportion, it must be considered that each company has a composition of assets and liabilities according to the necessity of its sector, its size and its market, among other factors.

In this sense, the focus of this work is not the study of accounting effects caused by reevaluation, but rather, the differences that exist in the indexes of companies that do and do not do reevaluation. Considering that comparability is lessened, company analysis is damaged, even for analysis through indexes, which considers proportions, relative values, not absolute values.

The fact that a company presents permanent assets in more realistic values in the face of an increase in net equity provides more realistic indexes of the company's economicfinancial condition, which can allow managers to make better decisions based on the numbers found in the indexes.

The tests performed in this study, respecting the limitations presented during the work, show that there are significant differences between the economic-financial indexes of companies that do and those that do not do reevaluation. This reinforces the discussion around loss of comparability in companies' accounting statements.

In this context, considering the analysis of statistical tests, it can be said that companies that do not do reevaluation present better financial indexes, therefore showing a better capacity of paying their obligations. This same group of companies presented better property structure indexes, thus showing a lower level of debt and of capital immobilization.

As for profitability, once again companies without reevaluation showed better indexes, that is, they presented better returns to investors and to their own activity.

It can be concluded, therefore, that companies which do not do reevaluation, in the group of companies studies, present better economic-financial indexes than companies that do reevaluation of fixed assets, besides, the analysis of company statements is damaged, due to the difference of fixed asset evaluation criteria.

\section{REFERENCES}

BRASIL. Decreto n 3.000 , de 26 de março de 1999. Estabelece critérios para tributação de pessoa jurídica.

BRASIL. Lei $\mathbf{n}^{\mathbf{0}}$ 6.404, de 15 de dezembro de 1976. Dispõe sobre as sociedades por ações. COMISSÃO DE VALORES MOBILIÁRIOS. Deliberação 183, de 19 de junho de 1995. Aprova pronunciamento do IBRACON sobre reavaliação de ativos. BBR, Braz. Bus. Rev. (Eng. ed., Online), 
CONSELHO FEDERAL DE CONTABILIDADE. Resolução CFC n⿳0 1.004/04. Aprova a NBC T 19.6 - Reavaliação de Ativos.

GIL, Antonio Loureiro. Como elaborar projetos de pesquisa. 4. ed. São Paulo: Atlas, 2001. HENDRIKSEN, Eldon S. e VAN BREDA, Michael F. Teoria da contabilidade. São Paulo: Atlas, 1999.

IUDICIBUS, Sérgio de. MARTINS, Eliseu e GELBCKE, Ernesto Rubens. Manual de Contabilidade das Sociedades por Ações: aplicável às demais sociedades / FIPECAFI. 6. ed. São Paulo: Atlas, 2003.

IUDICIBUS, Sérgio de. Teoria da contabilidade. 7. ed. São Paulo: Atlas, 2004.

MARION, José Carlos. Análise das demonstrações contábeis: contabilidade empresarial. São Paulo: Atlas, 2001.

MARTINS, Eliseu (org). Avaliação de empresas: da mensuração contábil à econômica. São Paulo: Atlas, 2001.

MARTINS, Eliseu. Reavaliação de bens. Caderno Temática Contábil IOB. V.25 n.35 p.298303. 1992.

MARTINS, Eliseu. Reavaliação, Correção Especial e Provisão para Imposto de Renda. Caderno Temática Contábil IOB. V.26 n.14 p.106-110. 1992.

MARTINS, Gilberto de Andrade. Estatística geral e aplicada. 2. Ed. São Paulo: Atlas, 2002. ATARAZZO, Dante Carmine. Análise financeira de balanços: abordagem básica e gerencial. 6. ed. São Paulo: Atlas, 2003.

SCHRICKEL, Wolfgang Kurt. Demonstrações Financeiras: abrindo a caixa preta: como interpretar balanços para a concessão de empréstimos. 2. ed. São Paulo: Atlas, 1999.

SCHVIRCK, Eliandro. A Reavaliação de ativos e seus impactos na análise das demonstrações contábeis no Brasil. Dissertação (Mestrado em Controladoria e Contabilidade) - Faculdade de Economia, Administração e Contabilidade. São Paulo: Universidade de São Paulo, 2006.

SILVA, José Pereira da. Gestão e análise de risco de crédito. 4. ed. São Paulo, Atlas, 2003.

STEVENSON, Willian J. Estatística aplicada à administração. São Paulo: Harbra, 2001. 